Biorheology Vol. 15, pp. 369-374.

Pergamon Press Ltd. 1978. Printed in Great Britain

\title{
CONVOCATION ADDRESS
}

FROM COLLOID SCIENCE TO BIORHEOLOGY - A HISTORICAL REMINISCENCE

Bun-ichi Tamamushi

Nezu Chemical Institute, Musashi University, Toyotama-kami 1-26, Nerimaku, Tokyo 176, Japan

Mr. President, Ladies and Gentlemen,

It is my honor and pleasure to have been invited to give a lecture for The Third International Congress of Biorheology held in this beautiful place of La Jolla, San Diego. In the plenary session called "Convocation" I was asked by Professor Fung, Chairman of the organizing Committee of the Congress, to talk about the past of the development of biorheology. However, I am afraid that my knowledge and experience in biorheology itself are not sufficient. I have rather been specializing in colloid and surface chemistry, now generally called 'Colloid Science'. Therefore, I would like to talk briefly about the subject following the title given in the programme.

From 1927 to '29 I stayed in Berlin, Germany, to study surface chemistry in Professor Freundlich's laboratory which belonged to the 'Kaiser Wilhelm-Institut für Physikalische Chemie'- now called'Fritz HaberInstitut der Max Planck-Gesellschaft'. Herbert Freundlich is, as is well known, one of the pioneers in the history of colloid science. My main interest in surface chemistry at that time was directed toward adsorption phenomena (1), but during my stay there I was able to observe some researches concerning rheology or biophysical chemistry carried on in the same laboratory.

Between 1922 and '26, the remarkable properties, such as viscoelasticity (Fliesselastizität) and thixotropy of some colloidal systems were discovered by Freundlich and his collaborators (2). While I was working there, the thixotropic and related behavior of iron- or vanadiumoxide sol were being studied in some details by K. Sollner (3), Professor Emeritus who, living at present in washington, D.C. is retired from the position he held at the National Institutes of Health. During the same period the sensitizing action of some proteins on the coagulation of ironoxide was being studied by $G$. Iindau (4) in comparison with the mechanism of agglutination phenomena of human blood. Lindau died in a plane accident during the war. Dr. Hans Zocher, who was senior assistant to Freundlich, was a specialist in colloid optics. Freundlich and zocher discovered with their collaborators the streaming double refraction and dichroism observed in vanadium-pentoxide or benzopurpurin sol, as well as tactoid formation in vanadium-pentoxide sol and Schiller-layer formation in iron-oxide sol, which contain anisometric (rod or plate shaped) particles (5). Zocher was also one of the pioneers in the study of mesomorphic phases (liquid crystals) (6). He became later Professor at the University of Prague and then moved to the Mineral Research Institute in Rio de Janeiro, Brazil, after the war.

Dr. Karl Weissenberg, whose name is well known to all present biorheologists, belonged at that time to the 'Kaiser Wilhelm-Institut für Theoretische Physik' directed by Prof. Albert Einstein. He often came to our Institut for Physical Chemistry, especially to Prof. Freundlich's and Prof. Michel Polanyi's laboratories. There he would receive some new informations pertaining to his interests and joined in discussions with our laboratory colleagues. I often saw him walking back and forth in the corridor of the institute, discussing some problems with Dr. zocher. I believe that his interest in viscoelastic behavior of materials and his later discovery of the 'Weissenberg-Effect' or his invention of the 'Weissenberg-Rheogoniometer' germinated in those free discussions. His 
desicn of the X-ray camera was also the product of his friendly association with Polanyi and his collaborators (7). We younger colleagues in the laboratory used to say jokingly: "Weissenberg dichtet im Kaffee am Vormittag", as he usually appeared in our Institute in the afternoon. After the war I met Weissenberg in 1963 in Providence, Conn. U.S.A., where The Fourth International Congress of Rheology was held. When I asked him why he was primarily interested in instrumentation, he answered that it was originally suggested by his teacher, Einstein.

After returning to my home country from Berlin, I received from Dr. Iindau a reprint of the paper on 'Thixotropy of Bentonite Suspensions' coauthored with Freundlich in 1931 (8). As soon as I read it, I began to make a research study on the similar behavior of some Japanese clay minerals. This study was continued, though being interrupted during the war time, up until 1960, parallel with the study of rheological properties of other colloidal systems (9). Meanwhile, I received from Freundich his monograph on 'Thixotropy' published in Paris (10) and some other reprints of papers on dilatancy and rheopexy written by him or by his collaborators during his stay in the University College of London, from 1933 to ' 38 after the Nazi domination of Germany. In 1938 Freundlich moved to the University of Minnesota as a Distinguished Service Professor in the Graduate School, but he passed away suddenly and lonely in 1941 from a heart attack. He maintained keen interests in biological problems throughout his career as a colloid scientist. His first monograph was 'Kapillarchemie and Physiologie' published in 1914 and his last paper was 'Some Mechanical Properties of Sols and Gels and Their Relation to Protoplasmic Structure' which was published in 1942 after his death (11). His obituary notices were presented by Prof. F.G. Donnan in London (12). As a man Freundlich was noble and warm-hearted just as his name stands out. We, students in Berlin, called him "Onkel Herbert" though it was not the German custom to say so directly to a professor. I do remember my teacher's advice for the research attitude in colloidal phenomena. He said that colloidal systems are generally too complicated to be explained straightforwardly, and, therefore, one must first seek out main parameters which are considered to control the phenomena and then by and by analyse them precisely as one unravels very much entangled string balls. This advice is applicable, I believe, also to biorheological research.

As is well known, the term 'Rheology' was first proposed by E.C. Bingham, an Americal physical chemist in 1929, when he met Freundich and Wo. Ostwald from Germany, H.R. Kruyt from Holland, M. Reiner from Haifa in Bingham's laboratory, G.W. Scott Blair from England and others at the Conference he organized in Washington, D.C. I myself did not know this term until I obtained Scott Blair's book: 'Survey of General and Applied Rheology' published in 1949. The term 'Biorheology' was first proposed by A.I. Copley in 1948 in his address at the First International Congress on Rheology, held in Scheveningen, Holland. I learned this from Scott Blair's recent book: 'An Introduction to Biorheology' published in 1974 (13).

It was in 1951, when I, with the help of my younger colleagues, Drs. Kambe and Nakagawa, f'irst organized a session on rheology in our Colloid Symposium of the Chemical Society of Japan. Since 1952 the Japanese Rheology Symposium has been held annually, and English abstracts of the contributed papers were distributed to main rheologists and rheology groups of foreign countries. The abstracts sent to Dr. Scott Blair were introduced to the participants of the Second International Congress on Rheology, held in Oxford, England in 1953 and thus the activities of Japanese rheologists became known in foreign countries. I first met Dr. Scott Blair in 1957 , when I visited England after the war, at his Institute in Reading and also at the Conference of the British Society of Rheology held in Welwyn Garden City. On that occasion I was able to recognize the interest and importance of rheological research for agricultural and biological materials.

In 1960 I received a letter from Scott Blair introducing Dr. A.I. Copley. At the same time I received a letter from Copley who was planning to make a lecture trip to Japan. With the help of my colleague Dr. Tomio Ogata of the medical faculty of the University of Tokyo, we asked Dr. Copley to deliver a lecture at a special plenary session of the International Congress on Blood Transfusion, held that year in Tokyo. Dr. Copley gave the lecture, entitled 'Hemorheology - An Introduction' (14). I attended the lecture with my friend, Dr. Syoten Oka, who is now President of the recently established Japanese Society of Biorheology. We were much stimulated by Copley's lecture and later Oka and I sat with our guest, 
Dr. Copley, in a small room at my house for several hours, talking about our common interests and discussing the plan of Copley and Scott Blair for the publication of the new international journal 'Biorheology'. Since that time Dr. Oka worked enthusiastically on biorheological problems from the standpoint of a theoretical physicist. In 1975, he received the 'Poiseuille Medal Award' at the Second International Congress of Biorheology held at the Weizmann Institute of Science in Rehovot, Israel (15). My main research field still remains in colloid and surface chemistry and my recent interest is centered around the molecular association phenomena of multi-component or multi-phase systems, which include problems of multi-adsorption layers, emulsions, microemulsions and mesomorphic phases or liquid crystals (16). I have been planning, however, to study these problems in connection with general rheology as well as with biorheology.

The following tables will hopefully supplement my lecture.

Table 1

Rheological Phenomena in Colloidal and Biological Systems and Early Investigators

Phenomena

Anomalous Viscosity

Plastic Flow

Viscoelasticity

Spinnability

Thixotropy, dilatancy

(Reynold's phenomenon)

Rheopexy

Streaming Double Refraction and Dichroism

Tactoid Formation

Surface Viscosity and Elasticity

Mesomorphic State

Protoplasmic Flow

Blood Flow

Biological Growth

\section{Investigators}

HATSCHEK, WO.OSTWALD, BINGHAM

BINGHAM

FREUNDLICH, SEIFRIZ

WEISSENBERG

OSTWALD, ERBRING

FREUNDIICH, SZEGVARI, SCHALEK,

JULIUSBURGER

FREUNDIICH, ZOCHER, BIRSTEIN, JACOBY

ZOCHER, STANLEY, BERNAL

JOIY, DERVICHIAN

FRIEDEI, ZOCHER, OSTWALD, LAWRENCE, EKWALL

HEILBRUNN, SEIFRIZ, KAMIYA

FAHRÄEUS, COPLEY, SCOTT BLAIR

KÜSTER, FREY-WYSSLING, WEISS 
TABLE 2

Freundlich's School in Rheological Research (1920 - 1940)

FREUNDLICH

SEIFRIZ

S ZEGVARI

SCHAIEK

Viscoelasticity

WEISSENBERG

SZEGVARI

SCHALEK

IINDAU

SOLLNER

JULIUSBURGER

TAMAMUSHI

Thixotropy

Dilatancy

Rheopexy

Coagulation

ZOCHER

BIRSTEIN

JACOBY

Streaming Double Refraction

Streaming Dichroism

Tactoid and Schiller Layer

SEIFRIZ

KAMIYA

Formation

Protplasmic Flow

TABLE 3

Rheology in Mesomorphic Systems

Phenomena

Anomalous Viscosity and Plastic

Flow in Nematic and Cholesteric

Liquid Crystals

Anomalous Viscosity, Plastic Flow

in Smectic Liquid Crystals

Rheology of Lyotropic Iiquid Crystals

Rheology of Liquid Crystals in Biological Systems

\author{
Investigator \\ OSTWALD \\ LAWRENCE \\ PORTER \\ JOHNSON \\ FUKADA \\ LUZZATI \\ LAWRENCE \\ TAMAMUSH I \\ EKWALI \\ MANDEI \\ FONTELI \\ FRIBERG \\ TAMAMUSHI \\ TIDDY \\ LUZZATI \\ CHAPMANN \\ IARSON \\ DINTENFASS
}


TABLE 4

Schemata for Biorheology as Interdisciplinary Science

Scott Blair

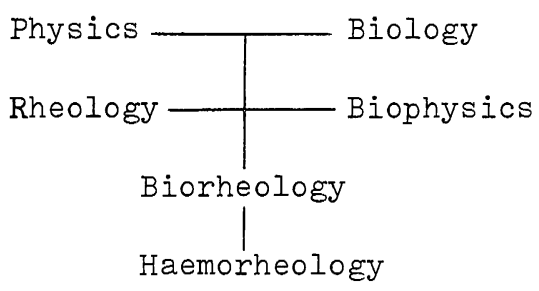

Tamamushi

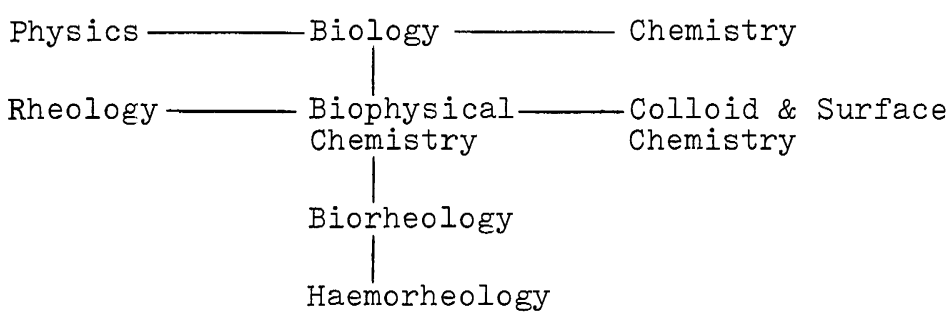

\section{ACKNOWLEDGMENT}

My thanks are due to Dr. N. Kamiya who kindly gave me information about the last paper of Prof. H. Freundlich, published by Dr. W. Seifriz in a Monograph on the Structure of Protoplasm in 1942 (11). 


\section{REFERENCES}

1. TAMAMUSHI, B. On the Derivation of Adsorption Isotherms.

Bul1. Chem. Soc. Japan, 1, 185-188, 257-260, 1926; ibid. 2, 299-303, 1927; ibid. 2, 142-146, 1928. Kol1. Z. 47, 58-60, 1929.

2. FREUNDIICH, H. Kapillarchemie, II, Akad. Verlag, Leipzig, 1932, pp. $302-317$.

3. FREUNDIICH, H. u. ZÖLLNER, K. Koll. Z. 45, 348, 1928.

4. IINDAU, G. Biochem. Z. 219, 385-408, 1930.

5. FREUNDIICH, H. Kapillarchemie, II, Leipzig, Akad. Verlag, 1932, pp. $40-61$.

6. ZOCHER, H. Liquid Crystals and Anisotropic Melts, A General Diss. Farad. Soc., 1933, pp. 945-957; Liquid Crystals 2, Proc. 2nd. Liq. Crys. Conf. Part 1, G. H. Brown (ed.), London-New York-Paris, Gordon and Breach, 1949, pp. 103-113; Liquid Crystals and Plastic Crystals. New York-Iondon-Sydney-Toronto, Ellis Horwood, Vol. 1, 1974, pp. 64-66.

7. The KARL WEISSENBERG 80th Birthday Celebration Essays, J. Harris (ed.), East African Literature Bureau, Nairobi, 1973.

8. FREUNDLICH, H., SCHVIDT, 0., IINDAU, G., Koll. Beihefte, 36, 43-81, 1932 .

9. The BUN-ICHI TAMAMUSHI'S Wo. Ostwald Prize Celebration Essays (in Japanese), T. Ando (ed.), Tokyo, 1976. Iist of Tamamushi's publications, pp. 87-101.

10. FREUNDIICH, H. Thixotropy, In: Actualités Sci. et Ind., 267, Paris, Hermann \& Cie, 1935.

11. FREUNDIICH, H. Kapillarchemie und Physiologie, Dresden-Leipzig, Th. Steinkopff, 1914; Some mechanical properties of sols and gels and their relation to protoplasmic structure: The Structure of Protoplasm - A Monograph, Amer. Soc. Plant Physiologists, W. Seifriz (ed.), Iowa State College Press, 1942, pp. 85-98.

12. DONNAN, G., HERBERT FREUNDLICH (1880-1941), Obituary Notices of Fellows of the Royal Society, Vol. 4 , Nov. 1942, pp. 27-50.

13. SCOTT BLAIR, G.W. An Introduction to Biorheology, Amsterdam-oxfordNew York, Elsevier, 1974, p. 2.

14. COPLEY, A.I., SCOTT BIAIR, G.W. Hemorheology - An Introduction, Proc. Internat. Soc. Blood Transfusion, Tokyo, 1960, I. Hollander (ed.), Basel, S. Karger, 1962, pp. 6-23.

15. OKA, S. Poiseuille Award Lecture: Present Status of Hemorheological Theory, Biorheology 12, 157-168, 1975.

16. TAMAMUSHI, B. Colloid and Surface Chemistry Aspects of Mesophases (Liquid Crystals): Pure and Applied Chemistry, 48, 1977, OxfordNew York-Frankfurt-Paris, Pergamon Press, pp. 44I-447. 